\title{
Perlindungan Hukum Nasabah sebagai Syarik dalam Pembiayaan Al Musyarakah di Bank Syariah Mandiri
}

\author{
Bagya Agung Prabowo \\ Fakultas Hukum Universitas Islam Indonesia \\ Jl. Tamansiswa No. 158 Yogyakarta \\ bagya@fh.uii.ac.id
}

\begin{abstract}
Musyarakah is a profit and loss sharing partnership. In Musyarakah financing, bank and customer contribute capital and skill in a project. The profit and loss will be normally divided based on the contribution. The discussed problem in this research is legal protection for customer in musyarakah financing and the legal status of guaranty and encumbrance in musyarakah financing of Yogyakarta Branch of Bank Syariah Mandiri. This research is a juridical empiric research. The secondary data is obtained by literary study from primary, secondary, and tertiary legal material. The result of this research showed that there must be equality in every transaction in Yogyakarta Branch of Bank Syariah Mandiri, because every financial process contains risk and profit in order to be a bound of trust which guarantees mudharib to find their obligation in the future as stipulated in musyarakah financing agreed before.
\end{abstract}

Key words: Musyarakah, legal protection, equality

\begin{abstract}
Abstrak
Musyarakah adalah kerjasama pembagian keuntungan dan kerugian. Dalam sebuah aturan musyarakah keuangan, bank dan nasabah keduanya menyumbangkan modal dan keahlian mereka dalam sebuah proyek. Keuntungan dan kerugian akan dibagi secara normal berdasarkan sumbangan modal. Permasalahan yang dikaji dalam penelitian ini adalah" Pertama, perlindungan hukum nasabah sebagai syarik dalam pembiayaan musyarakah; Kedua, kedudukan jaminan dalam pembiayaan musyarakah di Bank Syariah Mandiri Cabang Yogyakarta. Penelitian ini adalah penelitian empiris-juridis, untuk memperoleh data primer dalam bidang hukum. Data primer diperoleh melalui wawancara pada para pemberi informasi/informan. Untuk mendukung dan melengkapi data dalam bidang studi, studi pustaka dilakukan untuk data sekunder. Data sekunder diperoleh dari materi hukum primer, sekunder, dan tertier. Hasil dari penelitian ini menunjukkan bahwa setiap melakukan musyarakah keuangan di Bank Syariah Mandiri Cabang Yogyakarta harus menggunakan kesetaraan sebab setiap proses keuangan berisi resiko dan manfaatnya sebagai pengikat kepercayaan yang menjamin mudharib untuk menemukan obligasi mereka di masa depan, seperti yang dinyatakan dalam perjanjian musyarakah keuangan yang disepakati sebelumnya.
\end{abstract}

Kata kunci : Musyarakah, perlindungan hukum, kesetaraan. 


\section{Pendahuluan}

Pada dasarnya, aktivitas Bank Syariah tidak jauh berbeda dengan bank-bank konvensional yang telah ada. Perbedaan pokok antara keduanya terletak pada konsep dasar pemberian imbalan yang pada gilirannya menyebabkan perbedaan pada substansi dan bentuk operasionalnya. Sebagai lembaga yang keberadaannya masih relatif baru, tidak dipungkiri bahwa masih menghadapi permasalahan-permasalahan dalam melaksanakan aktivitasnya. ${ }^{1}$

Terlebih lagi mengingat salah satu kelemahan yang menyertai kehadiran bank dengan prinsip syariah ini ialah berprasangka baik kepada semua nasabahnya, berasumsi terhadap semua orang yang terlibat dalam Bank Syariah adalah jujur. Oleh karena itu bank ini sangat rawan terhadap mereka yang beritikad tidak baik, dengan kata lain bank berdasarkan prinsip syariah berisiko lebih tinggi dibanding bank konvensional. ${ }^{2}$ Sejalan dengan pernyataan di atas dalam menjalankan aktivitas usahanya, selain diawasi oleh Bank Indonesia, Bank Syariah juga diawasi oleh Dewan Pengawas Syariah. Pada dasarnya Dewan Pengawas Syariah merupakan suatu dewan yang dibentuk untuk mengawasi jalannya bank berdasarkan prinsip syariah agar dalam operasionalnya tidak menyimpang dari prinsip-prinsip muamalah menurut Syariah/Hukum Islam dan menguasai Hukum Dagang Positif serta berpengalaman dalam penyelenggaraan kontrak-kontrak bisnis.

Upaya pengembangan BSM di Indonesia tidak semata-mata hanya merupakan konsekuensi dari UU No. 10 Tahun 1998 yang merupakan payung hukum perbankan syariah saat itu, tetapi juga merupakan bagian dari upaya penyehatan sistem perbankan yang bertujuan meningkatkan daya tahan perekonomian nasional. Krisis ekonomi yang terjadi sejak akhir 1997 membuktikan bahwa bank yang beroperasi dengan prinsip syariah dapat bertahan di tengah gejolak nilai tukar dan tingkat suku bunga yang tinggi. Kenyataan tersebut ditopang oleh karakteristik operasional bank syariah yang melarang bunga (riba), transaksi yang bersifat tidak transparan (gharar) dan spekulatif (maysir). Pentingnya pengaturan perbankan syariah didasarkan pada pertimbangan bahwa bank syariah merupakan bagian dari sistem perbankan yang mempunyai sejumlah perbedaan karakteristik usaha dan sistem operasional

${ }^{1}$ Warkum Sumitro, Asas-asas Perbankan Islam dan Lembaga-Lembaga Terkait di Indonesia, Raja Grafindo Persada, Jakarta, 1992, hlm. 42

${ }^{2}$ Muchtar Syafi', "Manajemen Bank Syariah”, dalam Buku, Analisis Bank Syariah, BP-IPWI, Jakarta, 1995, hlm. 27 
dibandingkan dengan bank konvensional. Pengaturan yang bersifat spesifik dalam operasional perbankan syariah diperlukan untuk menjamin terpenuhinya prinsipprinsip syariah (comply to sharia principles).

Harus disadari bahwa lengkapnya peraturan dan infrastruktur saja belum cukup, sejumlah permasalahan lain masih ditemui dalam upaya pengembangan perbankan syariah, misalnya relatif rendahnya pemahaman masyarakat terhadap operasional pembiayaan dalam perbankan syariah. Salah satu bentuk pembiayaan dalam perbankan syariah tersebut adalah Al Musyarakah (persekutuan).

Idealitanya nasabah dalam pembiayaan Al Musyarakah dilindungi haknya sebagai syarik ${ }^{3}$ yang memiliki kedudukan setara dengan Bank yang juga sebagai syarik. Karena pada prinsipnya keduanya merupakan pihak yang sama-sama menyediakan modal untuk membiayai suatu proyek. Instrumen pembiayaan Al Musyarakah ini berdasarkan prinsip bagi-hasil dan mekanisme pengembalian yang fleksibel sesuai dengan realisasi usaha. Adapun fasilitasnya adalah mekanisme pengembalian pembiayaan yang fleksibel berdasarkan perhitungan revenue sharing. Realitanya pada Bank Syariah Mandiri, instrumen pembiayaan Al Musyarakah ini seolah-olah dipersamakan dengan pembiayaan Al Mudharabah, di mana nasabah sebagai mudharib diharuskan memberikan jaminan pada bank sebagai shahibul maal.

Idealitanya di dalam pembiayaan Al Musyarakah tidak mengharuskan adanya suatu jaminan, sebagaimana fatwa Dewan Syariah Nasional (DSN). Hal ini merupakan konsekuensi logis dari kedudukan yang setara (sama-sama sebagai syarik) antara nasabah dan bank, sehingga keuntungan ataupun risiko usaha proyek tersebut akan ditanggung bersama sesuai dengan kesepakatan. Namun realitanya di dalam pembiayaan Al Musyarakah, pihak Bank Syariah Mandiri senantiasa mensyaratkan adanya suatu jaminan. Sehingga tidak jelas bagaimana kedudukan jaminan dalam pembiayaan Al Musyarakah. Dengan demikian, masih banyak persoalan hukum yang perlu dikaji dan diteliti tentang perlindungan hukum nasabah sebagai syarik pada pembiayaan Al Musyarakah serta kajian mengenai apakah kedudukan jaminan dalam pembiayaan Al Musyarakah pada Bank Syariah Mandiri Cabang Yogyakarta sesuai dengan prisip hukum Islam. Karena itu, institusi perbankan syariah mesti dikelola secara hati-hati (prudent) sesuai dengan ketentuan undang-undang dan prinsip syariah yang tertuang dalam fatwa Dewan Syariah Nasional.

${ }^{3}$ Syarik adalah partner atau mitra yang bersama-sama menyediakan dana untuk mendanai suatu usaha tertentu dalam pembiayaan Al Musyarakah 


\section{Rumusan Masalah}

Pertama, bagaimanakah perlindungan hukum nasabah sebagai syarik dalam pembiayaan Al Musyarakah pada Bank Syariah Mandiri Cabang Yogyakarta? Kedua, bagiamanakah kedudukan jaminan dalam pembiayaan Al Musyarakah pada Bank Syariah Mandiri Cabang Yogyakarta?

\section{Tujuan Penelitian}

Pertama, untuk mengetahui bagaimanakah perlindungan hukum nasabah sebagai syarik dalam pembiayaan Al Musyarakah pada Bank Syariah Mandiri Cabang Yogyakarta. Kedua, untuk mengetahui bagaimana kedudukan jaminan dalam pembiayaan Al Musyarakah pada Bank Syariah Mandiri Cabang Yogyakarta sesuai dengan prinsip hukum Islam.

\section{Metode Penelitian}

Penelitian ini merupakan penelitian hukum normatif. ${ }^{4}$ Sifat penelitian yang dilakukan adalah deskriptif yang merupakan penelitian non hipotesa, sehingga penelitiannya tidak perlu merumuskan hipotesa. Sehubungan dengan penelitian deskriptif ini sering dibedakan atas dua jenis penelitian menurut proses, sifat dan analisis datanya. Adapun yang relevan untuk penelitian ini menurut peneliti adalah penelitian deskriptif yang bersifat eksploratif. ${ }^{5}$ Penelitian ini diharapkan memperoleh gambaran secara menyeluruh dan sistematis mengenai konstruksi hukum pembiayaan Al Musyarakah pada bank Syariah.

\section{Hasil dan Pembahasan}

\section{Perlindungan Hukum Nasabah sebagai Syarik dalam Pembiayaan Al Musyarakah}

Bank sebagai lembaga intermediary, salah satu fungsinya adalah memberikan pembiayaan (financing), yaitu pemberian fasilitas penyediaan dana untuk memenuhi hlm. 21

${ }^{4}$ Soerjono Soekanto, Faktor-Faktor Yang Mempengarubi Penegakan Hukum, Penerbit CV. Rajawali, Jakarta, 1983,

${ }^{5}$ Suharsimi Arikunto, Prosedur Penelitian: Suatu Pendekatan Praktik, Penerbit Bina Aksara, Jakarta, 1983, hlm. 33 
kebutuhan pihak-pihak yang memerlukan deficit unit. Dalam kegiatan penyaluran dana, bank syariah melakukan investasi karena prinsip yang digunakan adalah penanaman dana atau penyertaan dan keuntungan yang akan diperoleh bergantung kepada kinerja usaha yang menjadi objek penyertaan tersebut sesuai nisbah bagihasil yang telah diperjanjikan sebelumnya disebut pembiayaan, karena bank syariah menyediakan dana guna membiayai kebutuhan nasabah yang memerlukan dan layak memperolehnya. Dua jenis kegiatan tersebut sering diistilahkan dengan penyebutan yang sama, yaitu "pembiayaan".

Dari pembiayaan yang diberikan tersebut, maka pendapatan bagi-hasil atau keuntungan jual-beli yang memerlukan instrumen pembiayaan perbankan syariah merupakan sumber pendapatan yang dominan. Pada saat pemberian pembiayaan, terkandung di dalamnya risiko bagi bank dan pengusaha. Khusus kerugian yang dialami suatu bank, tidak saja merugikan bank itu sendiri tetapi juga berakibat kepada masyarakat penyimpan dan pengguna dana secara keseluruhan. Pihak bank dalam hal ini, sebagai upaya mengeliminasi kerugian yang terjadi, sejak dini harus menerapkan prinsip kehati-hatian dan asas pembiayaan yang sehat.

Perbankan syariah sebagai sub-sistem dari perbankan nasional dalam menerapkan prinsip kehati-hatian dan asas pembiayaan yang sehat, diwujudkan yang antara lain dengan adanya jaminan atau agunan (collateral) dari nasabah debitor. ${ }^{6}$

Jaminan atau agunan ini berfungsi untuk mendukung keyakinan bank atas kemampuan dan kesanggupan nasabah untuk melunasi pembiayaan yang diterimanya sebagaimana yang telah diperjanjikan. Jaminan tersebut sifatnya baik berupa materiil (kebendaan) maupun immaterial (perseorangan). ${ }^{7}$

Jaminan yang bersifat perorangan atau penanggungan dapat berbentuk jaminan pribadi (personal guarantee) maupun yang berbentuk jaminan perusahaan (company guarantee), sedangkan jaminan yang bersifat kebendaan termasuk mengenai pengikatan barang sebagai jaminan utang (agunan) antara lain diatur dalam ketentuan yang berlaku mengenai Hak Tanggungan, Hipotik, Jaminan Fidusia dan Gadai.

\footnotetext{
${ }^{6}$ Pasal 8 UU No. 10 Tahun 1998 jo No. 7 Tahun 1992 tentang Perbankan.

${ }^{7}$ Jaminan perorangan adalah suatu perjanjian antara seorang berpiutang (kreditor) dengan seorang ketiga yang menjamin dipenuhinya kewajiban-kewajiban si berutang (debitor). Ia bahkan dapat diadakan di luar (tanpa) sepengetahuan si berutang tersebut. Sedangkan jaminan kebendaan, dapat diadakan antara kreditur dengan debitunya, tetapi juga dapat diadakan antara kreditur dengan seorang ketiga yang menjamin dipenuhinya kewajiban-kewajiban si berutang (debitor). Lihat; R. Subekti, Jaminan-Jaminan Untuk Pemberian Kredit menurut Hukum Indonesia, Citra Aditya Bakti, Bandung, 1991, hlm. 15.
} 
Dalam Pasal 1820 KUHPerdata dinyatakan bahwa penanggungan adalah suatu persetujuan dengan mana seorang pihak ketiga, guna kepentingan si berpiutang, mengikatkan diri untuk memenuhi perikatannya si berutang manakala orang ini sendiri tidak memenuhinya.

\section{Pengertian Jaminan dalam Hukum Islam}

Dalam Hukum Islam, istilah jaminan atau penanggungan sebagaimana dimaksud Pasal 1820 KUHPerdata di atas, biasa dikenal dengan istilah kafalah. Sedangkan objek/barang yang dijaminkan dikenal dengan istilah rahn. Adapun bentuk pengikatan terhadap objek/barang yang dijaminkan, tidak diatur dan dinyatakan secara rinci, tetapi merupakan formulasi dari prinsip-prinsip umum dalam muamalah sesuai dengan kebiasaan (urf) dalam masyarakat.

Kafalah secara bahasa (Arab) dapat diartikan; menggabungkan (al dhammu), menanggung (hamalah), dan menjamin ( $\left.z a^{\prime} a m a h\right)$. Menurut istilah, kafalah adalah mempersatukan tanggung jawab dengan tanggung jawab lainnya dalam hal tuntutan secara mutlak, baik berkaitan dengan jiwa, utang, materi, maupun pekerjaan. Pengertian lain dari kafalah adalah jaminan yang diberikan oleh penanggung (kafiil) kepada pihak ketiga untuk memenuhi kewajiban pihak kedua atau yang ditanggung (makful'anhu, ashil). ${ }^{8}$

Rahn, secara bahasa berarti tetap dan lestari serta penahanan (al hasabu), sebagaimana dikatakan ni'matun rahinah, yang artinya "karunia yang tetap dan lestari” dan sebagaimana pula dijelaskan Al Qur'an, “Tiap-tiap pribadi terikat/ tertahan (rahinah) atas apa yang telah diperbuat" ${ }^{\prime 9}$. Terminologi rahn didefinisikan beberapa ulama fiqh sebagai berikut: 1. Ulama Malikiyah: "Harta yang dijadikan pemiliknya sebagai jaminan utang yang bersifat mengikat" 2. Ulama Hanafiyah: “Menjadikan sesuatu (barang) jaminan terhadap hak (piutang) yang mungkin sebagai pembayar hak (piutang) itu, baik seluruhnya maupun sebagian" 3. Ulama Syafi'iyah dan Hambaliyah: "Menjadikan materi (barang) sebagai jaminan utang yang dapat dijadikan pembayar utang apabila orang yang berutang tidak bisa membayar utangnya itu" ${ }^{10}$

${ }^{8}$ Wahbah Azzuhaili, Al Fiqh al Islam wa Adillatuhu, Damaskus, Dar al Fikr, 1989, Jilid V, hlm. 132; Sayyid Sabiq, Fiqh al Sunnah, Beirut, Dar al Fikr, 1992, jilid III, hlm. 283.

${ }^{9}$ Al Qur'an Surat: Al Mudatsir: 38

${ }^{10}$ Zainulbahar Noor, Membangun Citra Lewat Pengamalan Syariah, Grasindo, Jakarta, 1993, hlm. 42 
Dari definisi-definisi di atas dapat disimpulkan dengan pengertian rahn menurut Sayyid Sabiq, yaitu: "Ja'lu 'Ainin Laha Qimatun Maliyah fi Nadzri al Syar'i Bihaitsu Yumkinu Akhdzu al Dain au Akhdzu Ba'dhuhu Mintilka al 'Aini". ${ }^{11}$ Artinya, menjadikan barang yang mempunyai nilai harta menurut ajaran Islam sebagai jaminan utang, sehingga orang yang bersangkutan (kreditur) dapat mengambil piutang atau mengambil sebagian manfaat barang itu.

\section{Dasar Hukum Kafalah dan Rahn}

Pertama, dasar hukum kafalah, bersumber dari Al Qur'an, Al Sunnah dan Ijma, antara lain sebagai berikut: a. Al Qur'an, Ya'kub berkata: “Aku sekali-kali tidak akan melepaskannya (pergi) bersama-sama kamu, sebelum kamu memberikan kepadaku janji yang teguh atas nama Allah, bahwa kamu pasti akan membawanya kembali kepadaku..."12; b. Al Sunnah, Rasullah saw bersabda: “Utang itu harus ditunaikan dan orang yang menanggung itu harus membayarnya"13; c. Ijma' Ulama, para ulama madzab membolehkan akad kafalah ini. Orang-orang Islam generasi awal mempraktikkan hal ini, bahkan sampai saat ini tanpa ada sanggahan dari seorang ulamapun. ${ }^{14}$ Kebolehan akad Kafalah dalam Islam juga didasarkan pada kebutuhan manusia dan sekaligus untuk menghasilkan adanya kemudharatan bagi orang-orang yang berutang dan hal itu dapat dibantu oleh pihak lain.

Kedua, dasar Hukum Rahn, a. Al Qur'an, “Jika kamu dalam perjalanan (dan bermuamalah tidak secara tunai), sedang kamu memperoleh seorang penulis, maka hendaklah ada barang tanggungan yang dipegang oleh yang berpiutang....."15; b. Al Sunnah, "Dari A'masy, dari Ibrahim, dari Al Aswad ra, bahwa Nabi Muhammad saw membeli makanan dari orang Yahudi dengan cara ditangguhkan pembayarannya, kemudian nabi menggadaikan baju besinya" ${ }^{16}$; c. Ijma' Ulama, dari ayat Al Qur'an dan Hadits tersebut para ulama sepakat (ijma') bahwa barang sebagai jaminan hutang (rahn) dibolehkan (jaiz) baik dalam bepergian (safar) maupun tidak berpergian (safar). ${ }^{17}$

\footnotetext{
${ }^{11}$ Sayyid Sabiq, Op. Cit., hlm. 187

${ }^{12} \mathrm{Al}$ Qur'an Surat: Yusuf: 66

${ }^{13}$ Bihayatul Mujtabid wa Nihayatul Muqtasid, Vol. 3 Beirut Lebanon, Daar el Fikr, 1989, hlm. 212

${ }^{14}$ Sayyid Sabiq, Op. Cit., hlm. 284

${ }^{15}$ Al Qur'an Surat: Al Baqarah 283

${ }^{16}$ Taqiyuddin An Nabhani, Membangun Sistem Ekonomi Alternatif, Risalah Gusti, SUrabaya, 1996, hlm. 67

${ }^{17}$ Sayyid Sabiq, Op. Cit., hlm. 188
} 


\section{Ketentuan-ketentuan Berkaitan dengan Kafalah}

Adapun rukun kafalah sebagaimana yang disebutkan dalam beberapa literatur fiqh adalah; Pertama, pihak penjamin/ penanggung (kafil) telah baligh (dewasa) dan berakal sehat serta berhak penuh melakukan tindakan hukum dalam urusan hartanya dan rela (ridha) dengan tanggungan kafalah tersebut; Kedua, pihak yang berhutang (makful'anhu/'ashil) harus sanggup menyerahkan tanggungannya (piutang) kepada penjamin dan dikenal oleh penjamin; Ketiga, pihak yang berpiutang (makful lahu) diketahui identitasnya, dapat hadir pada waktu akad atau memberikan kuasa dan berakal sehat; Keempat, objek jaminan (makful bih); Merupakan tanggungan pihak/ orang yang berhutang (ashil), baik berupa uang, benda maupun pekerjaan; Bisa dilaksanakan oleh penjamin; Harus merupakan piutang mengikat (lazim) yang tidak mungkin hapus, kecuali setelah dibayar atau dibebaskan; Harus jelas nilai, jumlah dan spesifikasinya; Tidak bertentangan dengan syariah (tidak diharamkan). ${ }^{18}$

Mengenai objek tanggungan, menurut sebagian besar ulama fiqh adalah harta, hal ini didasarkan kepada hadits Nabi Muhammad saw: "Az za'imu gharimun" (Penanggung itu menanggung kerugian). ${ }^{19}$ Sehubungan dengan kewajiban yang harus dipenuhi oleh penanggung berupa harta, maka hal ini dikategorikan menjadi tiga hal, yaitu: a. tanggungan dengan utang, yaitu kewajiban membayar utang yang menjadi tanggungan orang lain dan dalam masalah utang, disyaratkan: 1) hendaknya nilai barang tersebut tetap pada waktu terjadinya transaksi tanggungan/jaminan. 2) bahwa barangnya diketahui, maka apabila tidak diketahui, dikhawatirkan akan terjadi gharar. b. tanggungan dengan materi, yaitu kewajiban menyerahkan materi tertentu yang berada di tangan orang lain. Jika berbentuk bukan jaminan seperti 'ariyah (pinjaman) atau wadi'ah (titipan), maka kafalah tidak sah. c. tanggungan dengan harta, yaitu jaminan yang diberikan oleh seorang penjual kepada pembeli karena adanya risiko yang mungkin timbul dari barang yang dijual-belikan. ${ }^{20}$

Wahbah Al Zuhaili dan Sayyid Sabiq memberikan penjelasan tentang pembagian kafalah sebagai berikut: ${ }^{21}$ a. Kafalah bil Mal, adalah jaminan pembayaran barang atau perlunasan hutang. Bentuk kafalah ini merupakan sarana yang paling luas bagi bank

${ }^{18}$ Wahbah Azzuhaili, Op. Cit., hlm. 140 - 147. Lihat juga, Dewan Syariah Nasional, Himpunan Fatwa DSN MUI, BI dan DSN, Jakarta, 2001, hlm. $72-73$.

${ }^{19}$ Bidayatul Mujtabid..., Op. Cit., hlm. 215

${ }^{20}$ Sayyid Sabiq, Op. Cit., hlm. $286-287$

${ }^{21}$ Ibnu Taimiyah, Majmu al Fatawa Shaikh al Islam, Maktabi al Riyadh, 1963, Vol. XXIX, Riyadh, hlm. 549 
untuk memberikan jaminan kepada para nasabahnya dengan imbalan fee tertentu. b. Kafalah bin Nafs, adalah jaminan diri dari si penjamin. Dalam hal ini bank dapat bertindak sebagai Judicial Personality yang dapat memberikan jaminan untuk tujuan tertentu. c. Kafalah bit Taslim, adalah jaminan yang diberikan untuk menjamin pengembalian barang sewaan pada saat masa sewa berakhir. Jenis pemberian jaminan ini dapat dilaksanakan oleh bank untuk keperluan nasabahnya dalam bentuk kerjasama dengan perusaahaan, leasing company. Jaminan pembayaran bagi bank dapat berupa deposito/tabungan dan pihak bank diperbolehkan memungut fee kepada nasabah tersebut. d. Kafalah al Munjazah, adalah jaminan yang tidak dibatasi oleh kurun waktu tertentu dan untuk tujuan/kepentingan tertentu. Dalam dunia perbankan, kafalah model ini dikenal dengan bentuk perfomance bond atau jaminan prestasi.

Menurut Wahbah Al Zuhaili, 22 kafalah ini pada dasarnya merupakan akad kebaikan

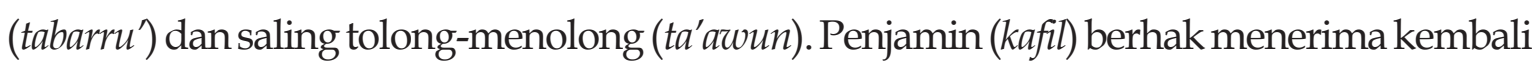
sejumlah jaminan yang diberikannya kepada orang yang dijamin (makful anhu) tanpa menerima tambahan (muqabil). Namun, bila orang yang menjamin mau memberikan hadiah atau imbalan, maka boleh menerimanya sesuai dengan kebiasaan ('urf).

Adapun menurut Abdul sa'i al Misri, ${ }^{23}$ seorang penanggung/ penjamin haruslah mendapatkan upah sesuai dengan pekerjaannya sebagai penjamin. Pendapat ini membuka peluang dimasukkannya pertimbangan besarnya risiko yang dipikul oleh si penjamin dalam memperhitungkan upahnya.

Akibat Hukum yang Timbul dari Kafalah adalah: Pertama, penjamin (kafil) wajib menjamin sepenuhnya apabila orang yang ditanggung tidak ada (pergi atau menghilang) dan ia tidak dapat keluar dari kafalah, kecuali dengan jalan memenuhi hutang yang menjadi beban 'ashil (orang yang ditanggung). Kedua, pemegang jaminan (makful lahu) berhak mengembalikan warkat penanggungan sehingga penanggungan dengan sendirinya menjadi batal $($ fasakh $) .{ }^{24}$

\section{Ketentuan-ketentuan Berkaitan dengan Rahn}

Para ulama figh berbeda pendapat dalam menetapkan rukun rahn, namun bila digabungkan, menurut jumhur ulama rukun rahn ada lima, yaitu: Rahin (orang yang

\footnotetext{
${ }^{22}$ Ibid.

${ }^{23}$ Zainul Arifin, Memahami Bank Syariah, Alvabet, Jakarta, 1999, hlm. 63

${ }^{24}$ Sayyid Sabiq, Ibid., hlm. 287
} 
menggadaikan), Murtahin (orang yang menerima gadai), Marhun (objek/barang gadai), Marhun Bih (hutang) dan Shigat (ijab-qabul). ${ }^{25}$

Para ulama figh mengemukakan syarat-syarat sesuai dengan rukun rahn itu sendiri, yaitu: a. Para pihak dalam pembiayaan rahn (Rahin dan Murtahin). Para pihak yang melakukan akad rahn adalah cakap bertindak menurut hukum (ahliyyah). b. Adanya kesepakatan Shigat (ijab-qabul). c. Marhun Bih (hutang), wajib dibayar kembali oleh debitur (Rahin) kepada kreditur (Murtahin), hutang boleh dilunasi dengan agunan dan hutang harus jelas dan tertentu (dapat dikuatifikasikan jumlahnya). d. Marhun (barang): 1) Karakteristik Barang, menurut ahli hukum Islam (fuqaha'), karakteristik barang jaminan hutang adalah sebagai berikut: a) Bernilai harta dan dapat diperjual-belikan, b) Jelas dan tertentu, c) Milik sah orang yang berutang, d) Tidak terkait dengan hak orang lain, e) Merupakan harta yang utuh, f) Boleh diserahkan baik materi maupun manfaatnya. 2) Jenis Barang, a) Berdasarkan Ketentuan Syariah, dengan melihat praktik Nabi Muhammad saw dan para sahabat, bahwa barang yang bisa dijadikan jaminan utang rahn dapat berupa kebun, baju besi dan hewan ternak. Oleh karena itu para ulama berpendapat bahwa barang yang dapat dijadikan jaminan hutang ( $\mathrm{rahn}$ ) pada prinsipnya adalah barang yang bergerak dan tidak bergerak. b) Penguasaan Barang yang Digadaikan, Para ulama sepakat bahwa rahn itu dianggap sempurna apabila barang yang digunakan itu secara hukum sudah berada di tangan pemberi hutang dan uang yang dibutuhkan telah diterima oleh peminjam hutang (rahin). Dengan adanya qabdhul marhun (penguasaan barang jaminan oleh murtahin), maka akad rahn bersifat mengikat kedua belah pihak.

Sebagaimana telah dikemukakan di atas bahwa dalam ketentuan syariah tidak diatur mengenai jenis pengikatan barang yang dijadikan sebagai jaminan hutang. Berdasarkan pemahaman terhadap QS. Al Baqarah : 283, maka barang yang dijadikan jaminan hutang harus diserahkan dan dikuasai oleh pemberi jaminan (murtahin).

Jumhur ulama selain ulama Hambaliyah berpendapat, bahwa pemegang barang jaminan tidak boleh memanfaatkan barang jaminan itu, karena bukan miliknya secara penuh. Hak pemegang barang jaminan terhadap barang itu hanyalah sebagai jaminan piutang yang ia berikan dan apabila orang yang berhutang tidak mampu melunasi hutangnya, barulah ia boleh menjual atau menaksir harga barang itu untuk melunasi piutangnya. Apabila ada kelebihan dalam penjualan tersebut, maka wajib dikembalikan kepada pemiliknya.

${ }^{25}$ M. Nejatullah Siddiqi, Kemitraan dan Bagi Hasil dalam Hukum Islam, Dana Bhakti Prima Yasa, Yogyakarta, 1996, hlm. 19 
Berakhirnya akad Rahn, menurut Wahbah Al Zuhaili adalah dikarenakan beberapa hal: ${ }^{26}$ a. Barang telah diserahkan kembali kepada pemiliknya, b. Rahin (penggadai) membayar hutangnya, c. Dijual paksa, yaitu dijual berdasarkan penetapan hakim atas permintaan Rahin, d. Rusaknya barang gadaian oleh tindakan/ penggunaan murtahin, e. Pembatalan oleh murtahin, meskipun tidak ada persetujuan dari pihak rahin, $\mathrm{f}$. Rusaknya barang gadaian oleh tindakan/penggunaan murtahin, g. Meninggalnya rahin (menurut Malikiyah) dan atau murtahin (menurut Hanafiyah), sedangkan Syafi'iyah dan Hambaliyah menganggap kematian para pihak tidak mengakhiri akad rahn.

\section{Jaminan Pembiayaan Al Musyarakah Pada Bank Syariah Mandiri}

Pada bank konvensional, "penanggungan" dalam praktiknya diterbitkan dalam bentuk Garansi Bank sebagaimana diatur di dalam Surat Edaran Direktur BI No. 23/7/UKU, tanggal 18 Maret 1991 tentang Pemberian Garansi Oleh Bank. Ditinjau dari perspektif hukum perbankan konvensional, kafalah (Garansi Bank) merupakan perjanjian penanggungan sebagaimana diatur dalam Pasal 1820 s/d Pasal 1850 KUH Perdata.

Adapun pada Bank Syariah Mandiri, berdasarkan hasil penelitian diketahui bahwa transaksi musyarakah dilandasi adanya keinginan para pihak yang bekerja sama untuk meningkatkan nilai asset yang mereka miliki secara bersama-sama. Semua bentuk usaha yang melibatkan dua pihak atau lebih di mana mereka secara bersama-sama memadukan seluruh bentuk sumber daya baik yang berwujud maupun tidak.

Secara spesifik bentuk kontribusi dari pihak yang bekerjasama dapat berupa dana, barang perdagangan (trading asset), kewiraswastaan (entrepreneurship), kepandaian (skill), kepemilikan (property), peralatan (equipment), atau intangible asset (seperti hak paten atau goodwill), kepercayaan/reputasi (creditworthiness) dan barangbarang lainnya yang dapat dinilai dengan uang. Dengan merangkum seluruh kombinasi dari bentuk kontribusi masing-masing pihak dengan atau tanpa batasan waktu menjadikan produk ini sangat fleksibel.

Ketentuan umumnya, semua modal disatukan untuk dijadikan modal proyek musyarakah dan dikelola bersama-sama. Setiap pemilik modal berhak turut serta dalam menentukan kebijakan usaha yang dijalankan oleh pelaksana proyek. Pemilik

${ }^{26}$ Wahbah Al Zuhaili, Op. Cit., jilid V, hlm. 288 - 289 
modal dipercaya untuk menjalankan proyek musyarakah tidak boleh melakukan tindakan seperti: 1. Menggabungkan dana proyek dengan harta pribadi, 2. Menjalankan proyek musyarakah dengan pihak lain tanpa ijin pemilik modal lainnya, 3. Memberi pinjaman kepada pihak lain.

Pada pembiayaan musyarakah ini setiap pemilik modal dapat mengalihkan penyertaan atau digantikan oleh pihak lain. Setiap pemilik modal dianggap mengakhiri kerjasama apabila: 1. Menarik diri dari perserikatan, 2. Meninggal dunia, 3. Menjadi tidak cakap hukum.

Biaya yang timbul dalam pelaksanaan proyek dan jangka waktu proyek harus diketahui bersama. Keuntungan dibagi sesuai porsi kesepakatan sedangkan kerugian dibagi sesuai dengan porsi kontribusi modal. Proyek yang akan dijalankan harus disebutkan dalam akad. Setelah proyek selesai nasabah mengembalikan dana tersebut bersama dibagi hasil yang telah disepakati untuk bank.

\section{Penutup}

Berdasarkan uraian di atas dapat disimpulkan bahwa, perlindungan hukum nasabah sebagai syarik dalam pembiayaan Al Musyarakah pada Bank Syariah Mandiri Cabang Yogyakarta dinilai masih lemah, yaitu pada awalnya merupakan akad tabarru' (kebaikan) dan ta'awun (saling tolong-menolong) antar sesama manusia, namun dalam perkembangannya sebagai salah satu bentuk usaha atau kegiatan pemberian pinjaman bank. Dalam Hukum Islam, istilah jaminan atau penanggungan sebagaimana dimaksud Pasal 1820 KUHPerdata, biasa dikenal dengan istilah kafalah. Sedangkan objek/barang dikenal dengan istilah rahn. Adapun bentuk pengikatan terhadap objek/barang yang dijaminkan tidak diatur dan dinyatakan secara rinci tetapi merupakan formulasi dari prinsip-prinsip umum dalam muamalah sesuai dengan kebiasaan ('urf) dalam masyarakat.

Dalam hal kekuatan mengikat akad jaminan pembiayaan Al Musyarakah pada Bank Syariah Mandiri Cabang Yogyakarta, ternyata hasil penelitian menunjukkan bahwa ketentuan syariah tidak mengatur mengenai jenis pengikatan jaminan (barang agunan). Oleh karena itu tata cara pengikatan terhadap barang agunan harus berpedoman kepada ketentuan-ketentuan yang berlaku dalam hukum konvensional sebagai ketentuan publik yang mengikat perbankan syariah di Indonesia, yaitu untuk barang tidak bergerak diikat secara Akta Pengikatan Hak Tanggungan dan Hipotik untuk Kapal. 
Al Musyarakah sebagai salah satu produk perbankan syariah yang didasarkan pada sumber Hukum Islam agar dapat dikembangkan sebagai produk unggulan pada perbankan syariah, maka perlu adanya perlindungan hukum nasabah sebagai syarik yang disosialisasikan secara terus-menerus terhadap para pengusaha dan kalangan perbankan untuk mempercepat pertumbuhan ekonomi dan mengentaskan kemiskinan melalui usaha-usaha produktif.

Dalam ketentuan perbankan syariah, pengikatan barang jaminan belum diatur secara rinci, sedangkan dalam ketentuan konvensional telah diatur secara rinci mengenai jenis pengikatan barang sebagai jaminan hutang (agunan) yang bersifat kebendaan, yaitu pengikatan hak tanggungan, hipotik, gadai dan jaminan fidusia. Maka sudah saatnya, kiranya, perbankan syariah memiliki komitmen untuk menerapkan Undang-Undang No 21 Tahun 2008 tentang Perbankan Syariah yang mengatur hal-hal yang mendasar tentang bank syariah. Penerapan undang-undang yang bersifat khusus ini sangat diperlukan mengingat perbedaan karakteristik yang sangat menonjol dalam praktik bank syariah bila dibandingkan dengan bank konvensional. Nilai-nilai syariah semestinya harus menjadi ruh penerapan ketentuan yang disusun dalam undang-undang itu sehingga diharapkan mampu membuka peluang sebesar-besarnya bagi kesejahteraan umat, meratanya distribusi pendapatan sehingga akan tercipta keadilan ekonomi di masyarakat.

\section{Daftar Pustaka}

An Nabhani, Taqiyuddin, Membangun Sistem Ekonomi Alternatif, Risalah Gusti, Surabaya, 1996.

Arifin, Zainul, Memahami Bank Syariah, Alvabet, Jakarta, 1999.

Arikunto, Suharsimi, Prosedur Penelitian: Suatu Pendekatan Praktik, Penerbit Bina Aksara, Jakarta, 1983.

Azzuhaili, Wahbah, Al Fiqh al Islam wa Adillatuhu, Damaskus, Dar al Fikr, Jilid V, 1989.

Bank Indonesia, Hal-hal Pokok dalam Undang-undang No. 7 Tahun 1992 tentang Perbankan, Jakarta, 1992.

Bidayatul Mujtahid wa Nihayatul Muqtasid, Vol. 3 Beirut Lebanon, Daar el Fikr, 1989.

Dewan Syariah Nasional, Himpunan Fatwa DSN - MUI, BI dan DSN, Jakarta, 2001.

Nejatullah Siddiqi, M., Kemitraan dan Bagi Hasil dalam Hukum Islam, Dana Bhakti Prima Yasa, Yogyakarta, 1996 
Noor, Zainulbahar, Membangun Citra Lewat Pengamalan Syariah, Grasindo, Jakarta, 1993.

Soekanto, Soerjono, Faktor-Faktor Yang Mempengaruhi Penegakan Hukum, Penerbit CV. Rajawali, Jakarta, 1983.

Subekti, R., Jaminan-Jaminan Untuk Pemberian Kredit menurut Hukum Indonesia, Citra Aditya Bakti, Bandung, 1991.

Sumitro, Warkum, Asas-asas Perbankan Islam dan Lembaga-lembaga terkait di Indonesia, Raja Grafindo Persada, Jakarta, 1992.

Syafi'i, Muchtar, Manajemen Bank Syariah, dalam Buku Analisis Bank Syariah, BP IPWI, Jakarta 1995.

Taimiyah, Ibnu, Majmu al Fatawa Shaikh al Islam, Maktabi al Riyadh, Vol. XXIX, Riyadh, 1963.

Surat Edaran BI No. 26/1/BPPP, 1993. 